University of Nebraska - Lincoln

DigitalCommons@University of Nebraska - Lincoln

2010

Uses of Youth Risk Behavior Survey and School Health Profiles Data: Applications for Improving Adolescent and School Health

Kathryn Foti

Centers for Disease Control and Prevention, htk7@cdc.gov

Alexandra Balaji

Centers for Disease Control and Prevention, abalaji@cdc.gov

Shari Shanklin

Centers for Disease Control and Prevention, bsa7@cdc.gov

Follow this and additional works at: https://digitalcommons.unl.edu/publichealthresources

Part of the Public Health Commons

Foti, Kathryn; Balaji, Alexandra; and Shanklin, Shari, "Uses of Youth Risk Behavior Survey and School Health Profiles Data: Applications for Improving Adolescent and School Health" (2010). Public Health Resources. 250.

https://digitalcommons.unl.edu/publichealthresources/250

This Article is brought to you for free and open access by the Public Health Resources at DigitalCommons@University of Nebraska - Lincoln. It has been accepted for inclusion in Public Health Resources by an authorized administrator of DigitalCommons@University of Nebraska - Lincoln. 


\section{Uses of Youth Risk Behavior Survey and School Health Profiles Data: Applications for Improving Adolescent and School Health}

Kathryn Foti, MPHa Alexandra Balaj, PhD b Shari Shanklin, MPH ${ }^{c}$

\section{ABSTRACT}

BACKGROUND: To monitor priority health risk behaviors and school health policies and practices, respectively, the Centers for Disease Control and Prevention (CDC) developed the Youth Risk Behavior Surveillance System (YRBSS) and the School Health Profiles (Profiles). CDC is often asked about the use and application of these survey data to improve adolescent and school health. The purpose of this article is to describe the importance and potential impact of Youth Risk Behavior Survey (YRBS) and Profiles data based on examples from participating sites.

METHODS: The authors spoke with representatives from 25 state and 8 local agencies funded by CDC to learn how data from the YRBS, Profiles, and other data sources are used. The authors identified common themes in the responses and categorized the responses accordingly.

RESULTS: Representatives indicated survey data are used to describe risk behaviors and school health policies and practices, inform professional development, plan and monitor programs, support health-related policies and legislation, seek funding, and garner support for future surveys. Examples presented highlight the range of possible uses of survey data.

CONCLUSIONS: State and local agencies use YRBS and Profiles data in many ways to monitor and address issues related to adolescent and school health. Innovative uses of survey data are encouraged, although it is also crucial to continue the more fundamental uses of survey data. If the data are not disseminated, the current health needs of students may not be adequately addressed.

Keywords: Youth Risk Behavior Survey; School Health Profiles; adolescent health; school health; data uses.

Citation: Foti K, Balaji A, Shanklin S. Uses of Youth Risk Behavior Survey and School Health Profiles data: applications for improving adolescent and school health. J Sch Health. 2011; 81: 345-354.

Received on August 24, 2009

Accepted on April 14, 2010

$\mathrm{T}$ he Centers for Disease Control and Prevention (CDC) developed the Youth Risk Behavior Surveillance System (YRBSS) to monitor priority health risk behaviors among high school students and the School Health Profiles (Profiles) to monitor school health policies and practices among secondary schools. The YRBSS provides data on the prevalence of 6 categories of priority health risk behaviors, including behaviors that contribute to violence and unintentional injuries; tobacco use; alcohol and other drug use; sexual behaviors that contribute to unintended pregnancy and sexually transmitted diseases, including human immunodeficiency virus (HIV) infection; unhealthy dietary behaviors; and inadequate physical activity. In addition, the YRBSS monitors the prevalence of obesity and asthma. ${ }^{1}$

The YRBSS includes a national school-based survey conducted by CDC, and state, territorial, tribal, and local school-based surveys conducted by state, territorial, tribal, and local education and health agencies. These surveys were first conducted in 1990 and have been conducted biennially since 1991. Each state, territory, tribal nation, or large urban school district, referred to in this article as "sites," uses a 2-stage cluster sample design to obtain a representative sample of students in grades 9-12. In 2007, 44 states, the District of Columbia, 5 territories, and 21 large urban school districts conducted a Youth Risk Behavior Survey (YRBS); 39 of 44 states, the District of Columbia, and all

a Health Scientist, (htk7@cdc.gov), Division of Adolescent and School Health, Centers for Disease Control and Prevention, 4770 Buford Hwy, NE, MS-K33, Atlanta, GA 30341. bEpidemiologist, (abalaji@cdc.gov), Division of HIV/AIDS Prevention, Centers for Disease Control and Prevention, 1600 Clifton Rd, MS-E46, Atlanta, GA 30333. cHealth Scientist, (bsa7@cdc.gov), Division of Adolescent and School Health, Centers for Disease Control and Prevention, 4770 Buford Hwy, NE, MS-K33, Atlanta, GA 30341. Address correspondence to: Kathryn Foti, Health Scientist, (htk7@cdc.gov), Division of Adolescent and School Health, Centers for Disease Control and Prevention, 4770 Buford Hwy, NE, MS-K33, Atlanta, GA 30341. 
participating territories and large urban school districts had weighted data that could be generalized to the entire high school population in the site's jurisdiction. ${ }^{1}$ Forty-seven states, the District of Columbia, 4 territories, 2 tribal governments, and 22 large urban school districts participated in the 2009 YRBS.

The School Health Profiles (Profiles) is a system of surveys assessing school health policies and practices among secondary schools in states, territories, tribal jurisdictions, and large urban school districts. Profiles helps education and health agencies monitor characteristics of school health education; school health policies related to HIV infection/acquired immunodeficiency syndrome (AIDS), tobacco use prevention, and nutrition; physical education; asthma management activities; and family and community involvement in school health programs. Profiles has been conducted biennially since 1996. Profiles uses random, systematic, equal-probability samples to produce data representative of schools with 1 or more of grades 6 through 12 in each site. At each selected school, the principal and lead health education teacher each complete a mailed questionnaire. In 2008, 50 states, the District of Columbia, 5 territories, 2 tribal nations, and 21 large urban school districts participated; 47 of 50 states, the District of Columbia, 4 territories, 2 tribal nations, and 20 large urban school districts obtained weighted data that could be generalized to all secondary schools in the jurisdiction. ${ }^{2}$

As more education and health agencies participate in these surveys and additional years of data are collected, CDC is increasingly asked about the application and use of survey data. In 1995 and 2001, CDC staff summarized ways that sites used their YRBS data. ${ }^{3,4}$ This article provides an update on the multitude of uses of YRBS data and summarizes for the first time how sites use Profiles data. Additionally, this article highlights ways that YRBS and Profiles data can be used to complement each other. CDC recognizes that many other rich sources of data are available through other national, state, and local surveys. Therefore, this article also provides examples of how YRBS and Profiles data can be used in combination with these data sources. The purpose of this article is to describe the importance and potential impact of YRBS and Profiles data based on examples from participating sites.

\section{METHODS}

\section{Subjects}

In fall 2008, the authors spoke via telephone to representatives from a purposive sample of 25 state agencies and 8 local agencies funded by CDC to identify how they use data from YRBS, Profiles, and other sources. The authors used several criteria to identify these agencies. First, because the intent of this project was to learn how the data are used and to gather examples of survey data uses which could be shared with and replicated by others, we contacted agencies that had previously used their survey data, based on our knowledge. Additionally, as we were interested in uses of YRBS and Profiles data, we focused on sites that achieved weighted data for both YRBS and Profiles. Further, the authors sought to interview agencies where one person was responsible for the coordination of both YRBS and Profiles and would be knowledgeable of data uses activities related to both surveys.

\section{Procedure}

The authors mailed letters to identified agency representatives explaining the purpose of this project and asking for their participation. Included in the information package was a copy of the paper by Sussman et $\mathrm{al}^{4}$ which previously summarized ways in which sites used their YRBS data; although we were interested in not only YRBS data uses here, we provided that article to help agency representatives think about some of the ways they might use their data and also to show them the type of article we intended to write based on the findings. The authors then called each agency representative to ask for their participation and to arrange a phone interview.

Each interview was conducted by 1 of the 3 authors. Interviews typically lasted 15 to 20 minutes. During the interview, the interviewer took detailed notes. The 3 authors met to review the notes during the course of the study; if further clarification about any of the examples was needed, the lead author contacted the agency representative for additional information.

\section{Instrument}

A semistructured interview form was used by all 3 authors when speaking with agency representatives. The interview began by asking the respondent, "Can you describe one or more specific examples of how your agency has used YRBS data?" The authors then allowed the respondent to offer as many examples as he or she wished. In the event that the respondent did not provide enough information, the authors would ask clarifying or probing questions to determine the format in which the data were disseminated and to whom the data were disseminated. The authors then followed the same procedure with respect to uses of Profiles data. Last, the authors asked the representative about whether their agency had ever used YRBS and Profiles data in combination with each other or in combination with any other data sources.

\section{Data Analysis}

Categories of survey data uses were identified by the authors post hoc. After the interviews were completed, the data uses examples from all sites were 
grouped by data source, ie, YRBS, Profiles, or a combination of data sources. The authors then reviewed all of the examples and identified common themes that emerged across data sources in the ways sites reported using their survey data. We found that the types of data uses sites reported were similar to those identified previously. ${ }^{4}$ After multiple iterations of how best to organize and present the responses, the authors developed the categories of survey data uses presented below and agreed on where each example belonged in the categorization scheme.

\section{RESULTS}

In speaking with state and local agencies, the authors found that survey data are used in the following ways: to describe risk behaviors and school health policies and practices; to inform professional development; to plan and monitor programs; to support health-related policies and legislation; to seek funding; and to garner support for future surveys.

Tables 1 through 6 provide examples of activities in each of these categories, arranged alphabetically by site name within survey data source. Some of the activities in the table are ongoing, while others have been completed. Unless otherwise noted, the activity is or was conducted by the state or local agency. A few selected examples in each table are described in detail below. The examples presented in this paper are not the only ways survey data can be used, but highlight the diversity and the range of possible data uses.

\section{Describe Risk Behaviors and School Health Policies and Practices}

Sites use YRBS and Profiles data, respectively, to describe youth risk behaviors and school health policies and practices in their jurisdiction. This is done in many ways, including posting results on an education or health agency Web site; printing materials such as reports, brochures, or fact sheets; disseminating press releases; giving presentations; and writing journal articles. Such products are geared toward many audiences, such as school board members, school administrators, teachers, school health services staff, parents, legislators, community health organizations, state or local education or health agency staff, and the general public.

The interviews showed that in many cases, sites use or adapt YRBS and Profiles products developed by CDC during the initial cleaning, editing, weighting, and analysis of data (Table 1, Section A). For example, North Carolina distributes its YRBS site report from CDC widely, including to all local education agencies and school health councils, while Kentucky posts the tables, graphs, and trend reports provided by CDC on its Web site. Arkansas, meanwhile, includes a link on its Web site to CDC's Youth Online, ${ }^{5}$ where users can view and compare YRBS results for each survey year that Arkansas had weighted data.

With regards to Profiles, New Hampshire posts the graphs and tables from its Profiles report from CDC on the state education agency Web site. New Hampshire also has used one of the fact sheets from CDC that compares state-specific Profiles data to the median among participating states to guide their programmatic efforts. Specifically, this fact sheet brought to the state's attention that, although New Hampshire's results were similar to or above the median for most variables, the percentage of lead health education teachers in the state who had professional preparation in health education was well below the median among all participating states. As a result, New Hampshire has placed a new emphasis on teacher preparation and the School Approval Team in the state has begun working on how to improve professional preparation in health education. Additionally, Los Angeles distributes fact sheets from CDC that combine both YRBS and Profiles data to state legislators, school board members, school administrators, and teachers, and also distributes them at community events.

In other instances, sites create their own YRBS and Profiles products or presentations to describe risk behaviors and school health policies and programs (Table 1, Section B). For example, Orange County (FL) created flipbooks with comparative data from the 2001, 2003, 2005, and 2007 YRBS surveys that have been distributed to their School Health Advisory Council, the Orange County Health Department, Teen Xpress, Planned Parenthood, local AIDS service providers, hospitals, and nurses. The flipbooks are also distributed at health fairs and are available to parents. Charlotte has created a variety of YRBS products such as tables, graphs, a summary report with highlights of the data, and a report on disparities. These resources were printed and also put on a compact disc, which was distributed widely to partners including the local health agency, Communities in Schools, Mecklenburg County Area Mental Health, and Teen Health Connection. Several sites issue press releases about YRBS survey results. For example, the Hawaii Department of Education has a memorandum of understanding with the Department of Health to do a joint press release on a different topic each month. YRBS data are often used in presentations and at conferences. For example, the Boston Public Health Commission included comparisons between YRBS data for Boston and the state of Massachusetts in a series of presentations given at community meetings in various city neighborhoods on the health status of Boston youth.

South Dakota created an executive summary of state Profiles results, which it shared with principals, health education teachers, and physical education teachers. They also displayed the summary at conference booths 


\begin{tabular}{|c|c|c|}
\hline Site & Data Source & Example Activity* \\
\hline \multicolumn{3}{|c|}{ A. Use or adapt products provided by CDC } \\
\hline Arkansas & YRBS & - Includes a link on its Web site to CDC's Youth Online \\
\hline Kentucky & YRBS & - Posts tables, graphs, and trend reports provided by CDC on its Web site \\
\hline New Mexico & YRBS & $\begin{array}{l}\text { - Provides copies of site report to each school district superintendent and } \\
\text { Coordinated School Health staff; plans to provide this year's report to school } \\
\text { principals }\end{array}$ \\
\hline North Carolina & YRBS & $\begin{array}{l}\text { - Distributes site report from CDC to all local education agencies and school health } \\
\text { councils }\end{array}$ \\
\hline Wisconsin & YRBS & - Makes PowerPoint slide set provided by CDC available on its Web site \\
\hline New Hampshire & Profiles & - Posts graphs and tables from CDC site report on its Web site \\
\hline New Hampshire & Profiles & $\begin{array}{l}\text { - Used fact sheet from CDC to help emphasize the need for teacher preparation in } \\
\text { health education in the state }\end{array}$ \\
\hline Los Angeles & Profiles, YRBS & $\begin{array}{l}\text { - Gives fact sheets from CDC to state legislators, school board members, school } \\
\text { administrators, and teachers; also distributes them at community events }\end{array}$ \\
\hline Montana, New York, South Dakota & Profiles, YRBS & - Post fact sheets from CDC that combine YRBS and Profiles data on their Web sites \\
\hline \multicolumn{3}{|c|}{ B. Create own YRBS and Profiles products } \\
\hline Arkansas & $\begin{array}{l}\text { YRBS (state and } \\
\text { national data) }\end{array}$ & $\begin{array}{l}\text { - Created a PowerPoint presentation comparing } 2007 \text { state results to } 2007 \text { national } \\
\text { results and posted it online }\end{array}$ \\
\hline Boston & $\begin{array}{l}\text { YRBS (local and state } \\
\text { data) }\end{array}$ & $\begin{array}{l}\text { - Showed comparisons between Boston and Massachusetts data in a series of } \\
\text { presentations at community meetings }\end{array}$ \\
\hline Charlotte & YRBS & $\begin{array}{l}\text { - Created a variety of products such as tables, graphs, a summary report, and a } \\
\text { disparities report } \\
\text { - Printed and put resources on a compact disc; distributed widely to partners }\end{array}$ \\
\hline Charlotte & $\begin{array}{l}\text { YRBS (local, state, and } \\
\text { national data) }\end{array}$ & $\begin{array}{l}\text { - Included data in presentations to the board of education, principals, the mayor's } \\
\text { advisory committee, the equity committee, the interfaith advisory council, and } \\
\text { community organizations } \\
\text { - Presentations showed } 2007 \text { results, comparisons to } 2005 \text { results, and how local } \\
\text { results compare to state and national results }\end{array}$ \\
\hline Georgia & YRBS & $\begin{array}{l}\text { - Produced a summary report with } 2007 \text { results and trends since } 2003 \text { by sex, } \\
\text { race/ethnicity, and grade } \\
\text { - Posted report on state health department Web site and sent copies to all public } \\
\text { middle and high schools, regional public health coordinators, and various public } \\
\text { health programs }\end{array}$ \\
\hline Hawaii & YRBS & - Includes data in monthly press releases \\
\hline Idaho & YRBS & $\begin{array}{l}\text { - Included data in presentations to the state health agency, state superintendent, } \\
\text { and state's first lady }\end{array}$ \\
\hline Kentucky & YRBS & $\begin{array}{l}\text { - Produced } 6 \text { fact sheets, each dedicated to } 1 \text { risk behavior category and posted } \\
\text { them on its Web site }\end{array}$ \\
\hline Mississippi & YRBS & $\begin{array}{l}\text { - Created a brochure that includes selected results and disseminated it to } \\
\text { superintendents, principals, school boards, district-level personnel, and legislators }\end{array}$ \\
\hline Montana & YRBS & $\begin{array}{l}\text { - Includes methamphetamine use data in a recurring report to the Montana Meth } \\
\text { Project and the governor's office }\end{array}$ \\
\hline Orange County (FL) & YRBS & $\begin{array}{l}\text { - Created and distributed flipbooks with comparative data from the 2001, 2003, } \\
\text { 2005, and } 2007 \text { surveys }\end{array}$ \\
\hline Orange County (FL) & YRBS & $\begin{array}{l}\text { - Used data in posters created for National Latino AIDS Awareness Day } \\
\text { - Distributed the posters to middle and high school human sexuality education } \\
\text { teachers, HIV prevention partners, and health clinics }\end{array}$ \\
\hline San Diego & YRBS & $\begin{array}{l}\text { - Writes an executive summary of the results for each survey year and sends it to } \\
\text { partner agencies and school administrators }\end{array}$ \\
\hline San Diego & YRBS & $\begin{array}{l}\text { - Included data in presentations to parents at parent preview meetings about sex } \\
\text { education }\end{array}$ \\
\hline Wisconsin & YRBS & $\begin{array}{l}\text { - Presented data on bicycling and helmet use to the governor's task force on biking } \\
\text { and walking }\end{array}$ \\
\hline Michigan & Profiles & $\begin{array}{l}\text { - Used data in presentations to the state board of education to help promote } \\
\text { wellness policies }\end{array}$ \\
\hline Missouri & Profiles & $\begin{array}{l}\text { - Uses data about vending machines in schools in presentations and wellness } \\
\text { policy workshops }\end{array}$ \\
\hline Nebraska & Profiles & - Used data to create a fact sheet on school health education \\
\hline New York & Profiles & - Used data to respond to media inquiries about school policies and programs \\
\hline South Dakota & Profiles & $\begin{array}{l}\text { - Created an executive summary and shared it with principals, health education } \\
\text { teachers, and physical education teachers; also displayed it at conference booths } \\
\text { and posted it online }\end{array}$ \\
\hline
\end{tabular}




\begin{tabular}{|c|c|c|}
\hline Site & Data Source & Example Activity* \\
\hline Missouri & Profiles, YRBS & $\begin{array}{l}\text { - Used data in presentations to show discrepancy between student (YRBS) and } \\
\text { teacher (Profiles) responses to questions about whether HIV prevention is taught } \\
\text { in schools }\end{array}$ \\
\hline Nebraska & Profiles, YRBS & $\begin{array}{l}\text { - Created fact sheets that included YRBS data and Profiles data showing what is } \\
\text { being done in schools to address relevant risk behaviors }\end{array}$ \\
\hline New Hampshire & Profiles, YRBS & $\begin{array}{l}\text { - Included Profiles results, along with selected YRBS data, in a pamphlet it gave to } \\
\text { the state attorney general; also distributed pamphlet at a violence prevention } \\
\text { conference and to law enforcement agencies }\end{array}$ \\
\hline \multicolumn{3}{|c|}{ C. Conduct further analyses of YRBS and Profiles data } \\
\hline Arkansas, Kentucky, New Hampshire, Houston & YRBS & $\begin{array}{l}\text { - Make the data set, or instructions for obtaining the data set, available on their Web } \\
\text { sites so others may conduct secondary analyses }\end{array}$ \\
\hline Charlotte & YRBS & $\begin{array}{l}\text { - Analyzed data to calculate disparity ratios comparing risk behavior prevalence } \\
\text { among black and Hispanic students to the prevalence among white students } \\
\text { - Published the results in a special report on racial/ethnic disparities }\end{array}$ \\
\hline Wyoming & YRBS & $\begin{array}{l}\text { - Analyzed data on dating violence victimization to define target populations for } \\
\text { programs and to look at associations between sexual violence and other risk } \\
\text { behaviors (Sexual Violence Coalition) }\end{array}$ \\
\hline Massachusetts & $\begin{array}{l}\text { YRBS, other data } \\
\text { sources }\end{array}$ & $\begin{array}{l}\text { - Merged YRBS data with data on school characteristics to look at how victimization } \\
\text { and suicidality among sexual minority students varies by school characteristics } \\
\text { - Published findings in a journal article }\end{array}$ \\
\hline Massachusetts & Profiles & $\begin{array}{l}\text { - Analyzed data to look at changes in school vending machine offerings over time } \\
\text { - Presented the results at a conference }\end{array}$ \\
\hline Massachusetts & $\begin{array}{l}\text { Profiles, other data } \\
\text { sources }\end{array}$ & $\begin{array}{l}\text { - Analyzed data from Profiles and a state questionnaire to examine changes over } \\
\text { time in health education; found that less time was spent on health education, in } \\
\text { particular, HIV prevention education, after funding was cut in } 2002 \\
\text { - Reported the findings in a special report about health education in the state }\end{array}$ \\
\hline
\end{tabular}

CDC, Centers for Disease Control and Prevention.

*Unless otherwise noted in parentheses, each activity is or was conducted by the state or local education or health agency.

and posted it online. Nebraska used Profiles data to create a fact sheet on school health education. They also created fact sheets that included YRBS data on relevant risk behaviors, and used Profiles data to show what is being done in schools to address problems such as alcohol use, inadequate nutrition and overweight, physical inactivity, sexual behaviors, tobacco use, violence and injuries, and suicide. Additionally, sites often use Profiles data in presentations. For example, the Missouri Health Department's nutrition program uses Profiles data about vending machines in schools for presentations and in wellness policy workshops.

Some sites conduct further analyses of YRBS and Profiles data or make the data sets available for others to conduct secondary analyses (Table 1, Section C). Sites have performed additional analyses to identify disparities, to examine results among priority subpopulations, and to look at associations between health risk behaviors or school health policies and practices. The results of these analyses have been used in reports, presentations, peer-reviewed scientific publications, and student dissertations. In Massachusetts, YRBS data were merged with data on school characteristics to look at how victimization and suicidality among sexual minority students varies by these characteristics. The results of this analysis, which showed that urban schools, schools with gay-straight alliances, and schools with higher proportions of racial/ethnic minorities were safer for sexual minority students, were published in a scientific journal. ${ }^{6}$

Although done less frequently, sites also conduct their own analyses of Profiles data. Massachusetts has analyzed Profiles data to look at changes in school vending machine offerings over time. The results of the analysis, showing areas of improvement and where attention was still needed, were presented at the annual Massachusetts Association of School Committees and Massachusetts Association of School Superintendents Joint Conference.

\section{Inform Professional Development}

Education agencies identify topics for professional development based on YRBS data and teachers' selfreported professional development needs from Profiles (Table 2). In Rhode Island, for example, a variety of professional development courses are conducted online and YRBS data are incorporated in those courses that focus on teaching sexually transmitted disease (STD) and HIV prevention and abstinence within a comprehensive sex education curriculum. In Wiscon$\sin$, materials for normative education, which aims to correct overestimation of peer risk behavior prevalence by students, have been created for health education teachers using YRBS data.

In Delaware, Profiles and other data sources were used to target professional development efforts around 
Table 2. Using Survey Data to Inform Professional Development

\begin{tabular}{|c|c|c|}
\hline Site & Data Source & Example Activity* \\
\hline Houston & YRBS & $\begin{array}{l}\text { - Uses data to inform teachers of risk } \\
\text { behavior prevalence and make teachers } \\
\text { aware of student experiences }\end{array}$ \\
\hline Idaho & YRBS & $\begin{array}{l}\text { - Incorporated data into trainings for health } \\
\text { educators on parent involvement, a key } \\
\text { component of their coordinated school } \\
\text { health model }\end{array}$ \\
\hline Rhode Island & YRBS & $\begin{array}{l}\text { - Included data in online professional } \\
\text { development courses about teaching } \\
\text { STD and HIV prevention and abstinence } \\
\text { within a comprehensive sex education } \\
\text { curriculum }\end{array}$ \\
\hline Wisconsin & YRBS & $\begin{array}{l}\text { - Used data to create materials for } \\
\text { normative education, which aims to } \\
\text { correct overestimation of peer risk } \\
\text { behavior prevalence by students }\end{array}$ \\
\hline Massachusetts & Profiles & $\begin{array}{l}\text { - Used data that showed teachers were not } \\
\text { covering food safety in their classes to } \\
\text { demonstrate the need for professional } \\
\text { development in this area }\end{array}$ \\
\hline Michigan & Profiles & $\begin{array}{l}\text { - Used data to support the need for } \\
\text { professional development and teacher } \\
\text { training around mental health } \\
\text { - Led to additional training in teacher } \\
\text { preparation programs }\end{array}$ \\
\hline San Diego & Profiles & $\begin{array}{l}\text { - Used data to show some school nurses } \\
\text { were not aware of school asthma } \\
\text { policies; Nursing and Wellness } \\
\text { Department now addresses policies } \\
\text { during school nurse trainings }\end{array}$ \\
\hline Delaware & $\begin{array}{l}\text { Profiles, other } \\
\text { data sources }\end{array}$ & $\begin{array}{l}\text { - Used Profiles and other data sources to } \\
\text { identify where professional development } \\
\text { efforts around sexual health curricula } \\
\text { were needed most } \\
\text { - Targeted professional development } \\
\text { efforts to those priority areas }\end{array}$ \\
\hline
\end{tabular}

*Unless otherwise noted in parentheses, each activity is or was conducted by the state or local education or health agency.

sexual health curricula. By creating a matrix that showed locations with high-risk populations for HIV infection and the schools where Profiles data indicated a need for further policy and curriculum development, Delaware was able to identify where professional development was most needed. In Michigan, the statewide planning group, formed after receiving the US Department of Education planning grant to integrate schools and mental health systems, used Profiles data to support the need for teacher preparation and professional development regarding mental health. Profiles data showed health education teachers received less professional development on mental health than on any other topic, and also that mental health was the topic on which teachers most wanted additional training. These findings helped drive statewide efforts to identify and provide professional development opportunities for teachers and led to partnerships with institutes of higher education to provide more training in this area in teacher preparation programs.

\section{Program Planning and Monitoring}

In response to needs identified using YRBS and Profiles data, sites will often implement health education curricula or develop health programs for schools and communities (Table 3). In addition to providing the rationale for such measures, survey data are critical in planning and monitoring program goals and objectives.

In Houston, the School Health Advisory Council relies heavily on YRBS data when reviewing school health programs and health education curricula and subsequently in making recommendations to the school board to ensure that programs and curricula best meet the needs of their students. For example, when reviewing sex education curricula, the School Health Advisory Council believed, given the YRBS data on the percentage of students who had had sexual intercourse, that abstinence-only sex education would not meet the needs of their students and therefore did not recommend abstinence-only programming to the school board. In Charlotte, YRBS data related to mental health led to the development of a video entitled, "Through My Eyes," about the stigma of mental illness as seen through the eyes of adolescents; various partners have since developed a curriculum to accompany the video, which is being integrated into ninth-grade health education courses. Working with the Nemours Foundation, Delaware used YRBS data on physical activity and nutrition to support the implementation of the "5-2-1-Almost None" program, which promotes eating at least 5 servings of fruits and vegetables per day, watching 2 or fewer hours of screen time a day, getting 1 or more hours of physical activity per day, and drinking almost no sugary beverages.

All sites interviewed routinely use Profiles data for strategic planning. All sites also use Profiles data to measure their School Level Impact Measures (SLIMs). SLIMs are based on a CDC-recommended policy or practice, monitor programmatic impact and success, and are an accountability mechanism for CDC's funded partners. Sites also use Profiles data for their own program planning and monitoring purposes. In Iowa, the Department of Public Health HIV Community Planning Group uses Profiles data on professional development, school policies, and health education on HIV prevention, along with YRBS and other data sources, to set prevention priorities and to choose target populations. In North Carolina, data from Profiles and YRBS combined with county health outcome data were used to develop aspects of the "Healthy Carolinians" objectives and standards. Charlotte monitors their progress toward these objectives using Profiles and other data sources. 


\begin{tabular}{|c|c|c|}
\hline Site & Data Source & Example Activity* \\
\hline Charlotte & YRBS & $\begin{array}{l}\text { - Used data related to mental health to develop video, "Through My Eyes," about the stigma of mental illness } \\
\text { - Integrated a curriculum developed to accompany the video into ninth-grade health education courses }\end{array}$ \\
\hline Delaware & YRBS & - Used physical activity and nutrition data to support implementation of the "5-2-1-Almost None" program \\
\hline Florida & YRBS & $\begin{array}{l}\text { - Used data for state-level strategic planning on substance abuse prevention and suicide prevention } \\
\text { (Workgroup composed of the Department of Education, the Department of Health, the Department of } \\
\text { Children and Families, the Department of Juvenile Justice, and the Governor's Office of Drug Control) }\end{array}$ \\
\hline Houston & YRBS & $\begin{array}{l}\text { - Uses data when School Health Advisory Council makes recommendations to the school board about school } \\
\text { health programs and health education curricula }\end{array}$ \\
\hline Massachusetts & YRBS & $\begin{array}{l}\text { - Compared data on sexual risk behaviors among Hispanic female students to female students of other } \\
\text { racial/ethnic groups to support the need for a Latina pregnancy prevention program (Massachusetts Alliance } \\
\text { on Teen Pregnancy) }\end{array}$ \\
\hline Montana & YRBS & $\begin{array}{l}\text { - Used trend data and data on special populations in its annual plan on tobacco use prevention among K-12 } \\
\text { students (Montana Tobacco Use Prevention Program) }\end{array}$ \\
\hline Nebraska & YRBS & $\begin{array}{l}\text { - Worked with a drug use prevention program, guidance counselors, family and consumer science teachers, } \\
\text { health and physical education teachers, school nurses, and health departments to establish curriculum } \\
\text { objectives based on data }\end{array}$ \\
\hline Nebraska & YRBS & $\begin{array}{l}\text { - Uses data to monitor } 21 \text { Critical Health Objectives that represent the most serious health issues among young } \\
\text { people, as established by the National Initiative to Improve Adolescent Health and the US Department of } \\
\text { Health and Human Services }\end{array}$ \\
\hline Wisconsin & YRBS & $\begin{array}{l}\text { - Used data to set priorities and long-term objectives in the overall state health plan, "Healthiest Wisconsin 2010" } \\
\text { - Uses the data currently to monitor progress toward those } 2010 \text { objectives }\end{array}$ \\
\hline All sites & Profiles & - Use Profiles data to measure their SLIMs \\
\hline Nebraska & Profiles & $\begin{array}{l}\text { - Used data to demonstrate to administrators the need for coordinated school health and the importance of } \\
\text { both health and physical education in schools, as opposed to just physical education }\end{array}$ \\
\hline San Francisco & Profiles & - Uses data to monitor programs and report on various grants \\
\hline Charlotte & Profiles, other data sources & - Uses Profiles and other data sources to monitor progress toward "Healthy Carolinians" objectives \\
\hline lowa & $\begin{array}{l}\text { Profiles, YRBS, other data } \\
\text { sources }\end{array}$ & $\begin{array}{l}\text { - Used Profiles data related to HIV prevention along with other data sources (including YRBS) to set prevention } \\
\text { priorities and choose target populations }\end{array}$ \\
\hline North Carolina & $\begin{array}{l}\text { Profiles, YRBS, other data } \\
\text { sources }\end{array}$ & $\begin{array}{l}\text { - Combined Profiles, YRBS, and county health outcome data to develop aspects of the "Healthy Carolinians" } \\
\text { objectives and standards }\end{array}$ \\
\hline
\end{tabular}

SLIMs, School Level Impact Measures.

* Unless otherwise noted in parentheses, each activity is or was conducted by the state or local education or health agency.

\section{Support Health-Related Policies and Legislation}

Education and health agencies use YRBS, Profiles, and other data to support health-related policies and legislation and to monitor implementation of policies and laws (Table 4). In Wyoming, YRBS data on alcohol use were used to help keep the minimum legal drinking age at 21 and are being used to support a related bill currently in the state legislature that would create an offense for those under 21 to enter bars and expand the offense for underage possession and consumption of alcohol, including that in the presence of their parent or guardian. In Mississippi, YRBS data were used to support the Mississippi Healthy Students Act (passed in 2007) which recognizes the relationship between healthy students and academic achievement and aims to keep students healthy by providing increased amounts of physical activity and health education and improved school nutrition programs.

In Arkansas, Profiles data have been used to assess knowledge and implementation of several components of Arkansas Act 1220 of 2003 to Combat Childhood Obesity, including provisions about vending machine offerings and access, and the requirement that all schools conduct the School Health Index every year. As a result of Profiles data, the Arkansas Department of
Education recently added a goal to its CDC work plan to strengthen school wellness committees and address gaps in knowledge and implementation through these committees. In Michigan, Profiles data have been used by the Healthy Kids, Healthy Michigan Coalition, which is composed of more than 100 partners from across the state and is focused on developing and implementing a 5-year policy agenda, to address childhood overweight in Michigan. The Education Policy Action Team of the coalition used Profiles data to better understand school health and physical education programs. The data were critical in crafting a bill recently introduced in the state senate requiring health education and physical education in every grade for grades K-8.

\section{Seek Funding}

Another key use of YRBS and Profiles data, as reported by many state and local agencies, is to secure funding (Table 5). In Mississippi, the Department of Mental Health used YRBS data to identify underage drinking as a priority health issue and applied for and received the Strategic Prevention Framework State Incentive Grant from the Substance Abuse and 
Table 4. Using Survey Data to Support Health-Related Policies and Legislation

\begin{tabular}{|c|c|c|}
\hline Site & Data Source & Example Activity* \\
\hline arlotte & YRBS & $\begin{array}{l}\text { - Required that training for staff on chronic } \\
\text { health issues be included in school wellness } \\
\text { policies as a result of asthma prevalence data } \\
\text { - Implemented restrictions on nondiet sodas in } \\
\text { schools as a result of nutrition data (District } \\
\text { superintendent) } \\
\text { - Strengthened the district's bullying policy and } \\
\text { allocated funding for education on bullying } \\
\text { prevention for staff, students, and parents as } \\
\text { a result of bullying data (District } \\
\text { superintendent) }\end{array}$ \\
\hline Chicago & YRBS & $\begin{array}{l}\text { - Used data on sexual activity to help establish } \\
\text { the Family Life and Comprehensive Sexual } \\
\text { Health Education Policy which implemented } \\
\text { age appropriate comprehensive sexual } \\
\text { health education starting at the fifth-grade } \\
\text { level; special training for fifth-grade teachers } \\
\text { also implemented }\end{array}$ \\
\hline Georgia & YRBS & $\begin{array}{l}\text { - Referenced the data in legislative sessions on } \\
\text { addressing obesity and improving physical } \\
\text { education }\end{array}$ \\
\hline Mississippi & YRBS & $\begin{array}{l}\text { - Used data to support the Mississippi Healthy } \\
\text { Students Act }\end{array}$ \\
\hline Texas & YRBS & $\begin{array}{l}\text { - Used data on physical activity and obesity to } \\
\text { support legislation for the Physical Fitness } \\
\text { Assessment Initiative, which requires all Texas } \\
\text { schools to use the FITNESSGRAM annually to } \\
\text { measure the fitness of students in grades } \\
\text { 3-12 }\end{array}$ \\
\hline Wyoming & YRBS & $\begin{array}{l}\text { - Used data on alcohol use to help keep the } \\
\text { minimum legal drinking age at } 21 \\
\text { - Using data to support another related bill in } \\
\text { the state legislature as well }\end{array}$ \\
\hline Arkansas & Profiles & $\begin{array}{l}\text { - Used data to assess knowledge and } \\
\text { implementation of Arkansas Act } 1220 \text { of } 2003 \\
\text { to Combat Childhood Obesity }\end{array}$ \\
\hline Michigan & Profiles & $\begin{array}{l}\text { - Used by the Healthy Kids, Healthy Michigan } \\
\text { Coalition to better understand school health } \\
\text { and physical education programs } \\
\text { - Used data to write state senate bill requiring } \\
\text { health and physical education in each of } \\
\text { grades K-8 }\end{array}$ \\
\hline New Mexico & Profiles & $\begin{array}{l}\text { - Found a discrepancy between principal and } \\
\text { teacher assessments of the amount of health } \\
\text { education being covered in the classroom; to } \\
\text { address this issue, the Public Education } \\
\text { Department embedded health education } \\
\text { into other statutory requirements and } \\
\text { required health education to be taught to } \\
\text { state health education standards } \\
\text { - Using data currently in the state legislature to } \\
\text { support making health education a required } \\
\text { course for graduation }\end{array}$ \\
\hline South Dakota & Profiles & $\begin{array}{l}\text { - Used data to help review the adequacy of the } \\
\text { state mandate on physical education and } \\
\text { support efforts to increase the number of } \\
\text { physical education credits required for } \\
\text { graduation }\end{array}$ \\
\hline
\end{tabular}

*Unless otherwise noted in parentheses, each activity is or was conducted by the state or local education or health agency.
Table 5. Using Survey Data to Seek Funding

\begin{tabular}{|c|c|c|}
\hline Site & Data Source & Example Activity* \\
\hline Hawaii & YRBS & $\begin{array}{l}\text { - Used data to protect funding for suicide } \\
\text { prevention programs (State legislature) }\end{array}$ \\
\hline Mississippi & YRBS & $\begin{array}{l}\text { - Used data to identify underage drinking as a } \\
\text { priority health issue and successfully apply for } \\
\text { grant funding (Department of Mental Health) }\end{array}$ \\
\hline Nebraska & YRBS & $\begin{array}{l}\text { - Use data to secure funding for federal and } \\
\text { state grant programs, such as Carol M. White } \\
\text { Physical Education Program (PEP) grants, } \\
\text { Nebraska Action for Healthy Kids grants, Dairy } \\
\text { Council of Nebraska grants, Tobacco Free } \\
\text { Schools/Communities grants, Safe Routes to } \\
\text { Schools grants, Fresh Fruit and Vegetable } \\
\text { grants, 21st Century Community Learning } \\
\text { Center grants, and HIV prevention education } \\
\text { grants (Schools and communities) }\end{array}$ \\
\hline Rhode Island & YRBS & $\begin{array}{l}\text { - Used data on sexual orientation and the } \\
\text { health risks facing sexual minority youth in } \\
\text { the state to apply for grant funding from the } \\
\text { Robert Wood Johnson Foundation on } \\
\text { same-sex dating violence (Community-based } \\
\text { organization) }\end{array}$ \\
\hline Wisconsin & Profiles & $\begin{array}{l}\text { - Used data to apply for the National Governors } \\
\text { Association Healthy Kids, Healthy America } \\
\text { grant to advance programs that help prevent } \\
\text { childhood obesity }\end{array}$ \\
\hline Wisconsin & Profiles & $\begin{array}{l}\text { - Used data to meet funding requirements of } \\
\text { the Wisconsin Department of Health Services; } \\
\text { used data to set and monitor priorities for the } \\
\text { School Tobacco Prevention Program }\end{array}$ \\
\hline
\end{tabular}

*Unless otherwise noted in parentheses, each activity is or was conducted by the state or local education or health agency.

Mental Health Services Administration's Center for Substance Abuse Prevention. In Hawaii, the state legislature has used YRBS data showing an increase in attempted suicide to justify and protect funding for suicide prevention programs.

In Wisconsin, the education agency used Profiles data in several grant applications, including the National Governors Association Healthy Kids, Healthy America grant to advance programs that help prevent childhood obesity and to develop the Healthier Wisconsin Schools project, which focuses on strengthening school health programs and policies that promote nutrition, physical activity, and maintaining a healthy body weight. The data also have been used to meet funding requirements of the Wisconsin Department of Health Services. Specifically, Wisconsin has used Profiles data to set program priorities and assess progress toward reaching those priorities for the School Tobacco Prevention Program.

\section{Garner Support for Future Surveys}

Sharing survey results with stakeholders can help them understand the purpose and value of survey participation (Table 6). For example, in both Delaware and New Mexico, stakeholders have met to review 
Table 6. Using Survey Data to Garner Support for Future Surveys

\begin{tabular}{|c|c|c|}
\hline Site & Data Source & Example Activity* \\
\hline Charlotte & YRBS & $\begin{array}{l}\text { - Included an overview of the YRBS and } \\
\text { why the district participates along } \\
\text { with survey results in presentations } \\
\text { to various partners }\end{array}$ \\
\hline $\begin{array}{l}\text { Delaware, New } \\
\text { Mexico }\end{array}$ & YRBS & $\begin{array}{l}\text { - Met to discuss current survey results } \\
\text { and future data collection needs } \\
\text { (Stakeholders) }\end{array}$ \\
\hline Kansas & YRBS & $\begin{array}{l}\text { - Developed booklet describing } 2007 \\
\text { results and included examples of } \\
\text { what schools are doing to address } \\
\text { each of the } 6 \text { priority risk behavior } \\
\text { areas; also included information on } \\
\text { how the YRBS is conducted } \\
\text { - Booklet part of package sent to } \\
\text { schools asked to participate in the } \\
2009 \text { YRBS }\end{array}$ \\
\hline New York & YRBS & $\begin{array}{l}\text { - Includes fact sheets as part of the } \\
\text { clearance package for the next YRBS }\end{array}$ \\
\hline Nebraska & $\begin{array}{l}\text { YRBS, other } \\
\text { data sources }\end{array}$ & $\begin{array}{l}\text { - Created a document, "School Based } \\
\text { Public Health Surveys in Nebraska," } \\
\text { to explain to schools the different } \\
\text { youth surveys that are conducted in } \\
\text { the state; for each survey, the } \\
\text { document details the topics covered, } \\
\text { who conducts the survey, who is } \\
\text { eligible to participate, how the } \\
\text { sample is selected, when the survey } \\
\text { is conducted, how the information is } \\
\text { used, and why participation in the } \\
\text { survey is important }\end{array}$ \\
\hline North Carolina & Profiles, YRBS & $\begin{array}{l}\text { - Includes links on its Web site for those } \\
\text { who use YRBS or Profiles data to } \\
\text { report examples of data uses; } \\
\text { information is used to support future } \\
\text { survey implementation }\end{array}$ \\
\hline
\end{tabular}

*Unless otherwise noted in parentheses, each activity is or was conducted by the state or local education or health agency.

current YRBS results, discuss data collection needs, and determine which questions to include on future surveys. Additionally, the North Carolina Department of Public Instruction collects its own examples of survey data uses to show the value of survey data and support future implementation of YRBS and Profiles. The department's Web site includes links for those who use YRBS or Profiles data in North Carolina to e-mail their examples of data uses to the department.

\section{DISCUSSION}

State and local health and education agencies use YRBS and Profiles, along with other data sources, in many ways to monitor and address adolescent and school health issues. Sites have used their survey results to describe youth risk behaviors and school health programs, inform professional development, plan and monitor programs, support health-related policies and legislation, seek funding, and garner support for future surveys. The examples presented show that there is a wide range of possible uses of survey data. These examples also show that, when used effectively, survey data are valuable to health and education agencies and their partners, and ultimately to students.

As state and local agencies continue to conduct the YRBS and Profiles, the amount of data available on youth risk behaviors and school health programs will continue to increase. Additionally, agencies will have increased ability to monitor trends over time. Therefore, the value of survey data will only continue to grow. In the future, new technologies and new media will provide innovative ways to use the survey data and to reach new audiences. Although there are a multitude of activities that can be done with survey data and creativity is encouraged, it is important to remember that some of the more fundamental uses of survey data, such as to describe students' behaviors and schools' policies and programs, are critical. If YRBS and Profiles data are not disseminated and used to improve school health policies and practices, the current health needs of students may not be adequately addressed.

\section{Limitations}

Our work is limited in that we did not speak with all agencies that conduct YRBS or Profiles to learn about how they use their survey data. Some of these agencies may use their data effectively as well. However, the purpose of this project was to learn more about how agencies use their data and to collect examples to share with other agencies seeking new and improved uses of their own survey data. By targeting certain agencies for inclusion in this study, we believe we achieved this aim. Further, although we may have missed some interesting examples of survey data uses, we believe that the major categories of data uses were captured from the multiple examples provided by agency representatives.

\section{IMPLICATIONS FOR SCHOOL HEALTH}

YRBS and Profiles data provide state and local agencies with important information about youth risk behavior engagement and school health policies and practices. It is critical for these agencies to understand and share their data to better address the health needs of students. This article describes 6 broad categories of data uses and presents specific examples of how agencies have used survey data. School health stakeholders can adopt the examples presented here or use these examples to help develop their own ways of using their survey data. The fundamental message is that survey data can help drive school health policies, programs, legislation, and funding, but only if the results are disseminated and applied to school health improvement efforts. 


\section{Human Subjects Approval Statement}

This project was exempt from institutional review board review.

\section{REFERENCES}

1. Eaton DK, Kann L, Kinchen S, et al. Youth Risk Behavior Surveillance-United States. MMWR Surveill Summ. 2008;57(4): $1-131$.

2. Brener ND, McManus T, Foti K, et al. School Health Profiles 2008: Characteristics of Health Programs Among Secondary Schools. Atlanta, GA: Centers for Disease Control and Prevention; 2009.
3. Everett SA, Kann L, McReynolds L. The Youth Risk Behavior Surveillance System: policy and program applications. J Sch Health. 1997;67(8):333-335.

4. Sussman MP, Jones SE, Wilson TW, Kann L. The Youth Risk Behavior Surveillance System: updating policy and program applications. J Sch Health. 2002;72(1):13-17.

5. Centers for Disease Control and Prevention. Youth Online: Comprehensive results. Available at: http://apps.nccd.cdc.gov/yrbss. Accessed August 24, 2009.

6. Goodenow C, Szalacha L, Westheimer K. School support groups, other school factors, and the safety of sexual minority adolescents. Psychol Sch. 2006;43(5):573-589.

- Dept. of Health Education and Behavior, University of Florida, Florida Gym,
- Gainesville, FL 32611
- Seminole Tribe of Florida, 6300 Stirling Road, Hollywood, FL 33024
Gold Endowment Partner
- College of Public Health, University of South Florida, 13201 Bruce B. Downs Blvd.,
MDC 56, Tampa, FL 33612
- Dept. of Applied Health Science, Indiana University, HPER 116, Bloomington, IN 47405
- SOJO Hand Hygiene Program, GOJO Industries, PO Box 991, Akron, OH 44309.0991
- Teenvillage.org
- The Prevention Researcher, 66 Club Road, Suite 370, Eugene, OR 97401
Silver Endowment Partner
- American Cancer Society, 3709 West Jetton Ave., Tampa, FL 33629
- The SPARK Programs, 438 Camino Del Rio South, Suite 110, San Diego, CA 92108
Sustaining Partner
- College of Health and Social Services, New Mexico State University, PO Box 30001,
MSC 3446, Las Cruces, NM 88003
- National Association of State School Nurse Consultants (NASSNC); www.nassnc.org
- Susan Spalt, Carrboro, NC
Century Partner
- Risse Brothers, 1710 N. Hercules Ave., Clearwater, FL 33765
4340 East West Highway - Suite 403 - Bethesda, MD 20814 . 301/652-8072 - www.ashaweb.org
A

